\title{
Findings About Events or Interventions Collection Date Time
}

National Cancer Institute

\section{Source}

National Cancer Institute. Findings About Events or Interventions Collection Date Time.

NCl Thesaurus. Code C113360.

The date and time that a finding about an event or intervention was collected. 